\title{
Tranh Bùi Xuân Phái hay chiếc Macbook: nghiên cứu về thực trạng tranh giả ở Việt Nam
}

\author{
Vũ Hoàng Giang (Giang Gy) \\ E-mail: gianggy11@gmail.com
}

Hà Nội, 01-01-2019

Nếu một tên trộm lẻn vào nhà một đại gia và đứng giữa sự lựa chọn trộm một bức tranh của Bùi Xuân Phái hay một chiếc Macbook, giả sử cả hai đều có giá trị và kích thước tương đương, dám chắc là hắn sẽ chọn chiếc Macbook.

Tại Việt Nam, chính nạn tranh giả lại là kẻ thù số một của nạn trộm tranh. Thực tế, các bảo tàng, gallery hay phòng trưng bày cá nhân tại Việt Nam chưa phải đối mặt với mối đe doạ từ những kẻ trộm tranh như các nước khác: vụ trộm bức Mona Lisa năm 1911 hay bức The Scream năm 1994. Đây là một phát hiện thú vị trong nghiên cứu về thực trạng tranh giả ở Việt Nam công bố hồi tháng 10-2018 tạp chí Arts [1]. Các tác giả người Việt đã đưa ra những phân tích về giá trị thị trường của tranh Việt trong nước và quốc tế, và ảnh hưởng của nạn tranh giả đến hội họa Việt Nam. Chủ đề mới lạ và cách tiếp cận độc đáo của nghiên cứu đã gây được sự chú ý với bạn bè quốc tế và hiện bài viết này thuộc top truy cập nhiều nhất và đọc nhiều nhất của tạp chí Arts [2].

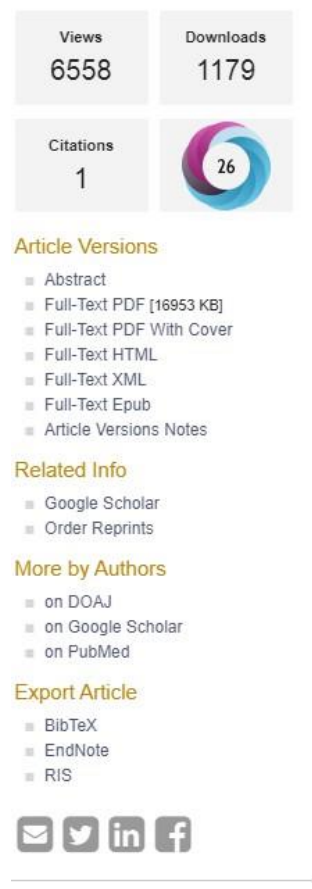

\section{Abstract}

A work of Vietnamese art crossed the million-dollar mark in the international art market in early 2017. The event was reluctantly seen as a sign of maturity for Vietnamese art amidst many problems. Even though the media in Vietnam has discussed the problems enthusiastically, there is a lack of literature from Vietnamese academics on the subject, especially from the market perspective. This paper aims to contribute an insightful perspective on the Vietnamese art market through the lens of art frauds. Thirty-five cases of fraudulent paintings were found on the news and in stories told by art connoisseurs. The qualitative analysis of the cases has shown that the economic value of Vietnamese paintings remains high despite the controversial claims about their authenticity. Here, the Vietnamese authority seems indifferent to the problem of art frauds, which make the artists more powerless. While the involvement of foreign actors in the trading of Vietnamese art does not reduce the intensity of the problem, it seems to continue to drive the price higher. The results have implications on the system of art in Vietnam, the current state of art theft in Vietnam, and the perception of Vietnamese people on art. View Full-Text

Keywords: Vietnamese art, Vietnamese art market; fake painting; art fraud; art crime

$\checkmark$ Figures

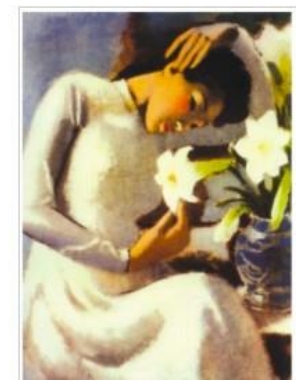


Bất chấp việc tranh giả xuất hiện phổ biến, giá tranh Việt vẫn tiếp tục tăng trong thời gian qua tuy nhiên sự tăng trưởng của thị trường tranh Việt chưa thực sự bền vững. Trên hết, tranh cần được coi là tài sản giá trị thay vì chỉ là một vật trang trí. Tính đơn nhất là một tính chất quan trọng làm nên giá trị tranh nhưng gặp một cản trở là thái độ khoan dung trước việc sao chép và làm giả tranh xuất hiện phổ biến tại Việt Nam. Điều này bắt nguồn từ thực tế rằng các hoạ sĩ Việt Nam từ lâu có thói quen tự sao chép tác phẩm của mình.

Ngày 6/12 vừa qua, Cục Mỹ thuật, Nhiếp ảnh và Triển lãm đã ra mắt Trung tâm Giám định và Triển lãm tác phẩm mỹ thuật, nhiếp ảnh [3]. Những cuộc tranh cãi về tranh thật tranh giả vẫn tiếp tục diễn ra nhưng từ nay sẽ có thể được phân định trắng đen một cách thuận lợi hơn bởi một cơ quan thẩm quyền. Đồng thời, những khái niệm về tranh giả, tranh nhái (fake, forgery, copied, plagiarism arts) hy vọng sẽ được định

nghĩa rõ ràng bằng văn bản để thị trường tranh Việt có một luật chơi rõ ràng và minh bạch hơn.

\section{References:}

[1] Vuong, Q.H., Ho, M.T., Vuong, T.T., Tran, K., \& Ho, M. (2018b). "Paintings can be forged, but not feeling": Vietnamese art-Market, fraud, and value. Arts, 7(4), 62, doi: $10.3390 / \operatorname{arts} 7040062$.

[2] SSHPA SciComm. (2018). Cảm xúc hội họa đầu tuần. Địa chỉ: https://sc.sshpa.com/post/4343 (Truy cập: 01-01-2018).

[3] NH. (2018). Ra mắt Trung tâm Giám định và Triển lãm tác phẩm mỹ thuật, nhiếp ảnh. VGP News. Địa chỉ: http://baochinhphu.vn/Van-hoa/Ra-mat-Trung-tamGiam-dinh-va-Trien-lam-tac-pham-my-thuat-nhiep-anh/354010.vgp (Truy cập: 01-01-2018). 